\title{
Aku Membelinya Bukan Karena Aku Suka: Bagaimana Nilai (Personal dan Berbelanja) Memengaruhi Tendensi Pembelian Impulsif
}

\author{
Novika Grasiaswaty ${ }^{1 *}$, Maria Santi Widyartini' ${ }^{2}$, \& Rury Ervina Siregar ${ }^{3}$ \\ ${ }^{1}$ Fakultas Psikologi, Universitas YARSI, Jakarta \\ ${ }^{2}$ Trikharisma Consulting \\ ${ }^{3}$ Independent Researcher
}

\begin{abstract}
Abstrak
Penelitian ini bertujuan untuk memahami peranan nilai personal dan nilai perilaku berbelanja dalam menjelaskan tendensi seseorang untuk membeli secara impulsif. Untuk mengembangkan penelitian sebelumnya, pada penelitian ini kami juga menambakan nilai berbelanja (shopping values) dalam analisis. Penelitian dilakukan pada 164 orang $(74,4 \%$ perempuan) dengan survei secara online. Data diolah dengan regresi hierarki dengan memasukkan data demografis di tahapan pertama, lalu nilai personal di tahapan kedua, dan nilai berbelanja di tahapan kegiatan. Hasil penelitian menunjukkan bahwa nilai berbelanja memprediksi tendensi pembelian impulsif, khususnya nilai hedonic. Sementara itu, nilai personal tidak memiliki peranan signifikan dalam memprediksi kecenderungan pembelian impulsif. Analisis lebih lanjut terhadap dimensi-dimensi nilai personal menunjukkan bahwa hanya nilai humility (kesederhanaan) yang memprediksi tendensi dalam pembelian impulsif sedangkan untuk nilai berbelanja, sementara nilai face, hedonistic, power resource, dan power dominance tidak memiliki peranan signifikan dalam menjelaskan kecenderungan pembelian impulsif.
\end{abstract}

Kata kunci: impulsive buying, nilai personal, orang Indonesia

\begin{abstract}
Present study attempts to examine the role of personal values in explaining impulsive buying. To extend previous studies, we also examine the role of shopping values in the analysis. We employed 164 individuals as participants ( $74.4 \%$ women) by administering an online survey. We analyzed the data with hierarchical regression by including demographic variables at the first stage, personal values at the second stage, and shopping values. The results revealed that only shopping values that affect the tendency of impulsive purchases, in particular hedonic values. Meanwhile, personal values did not significantly predict the outcome variable. Moreover, analysis on domains of personal value showd that humility was the only significant predictor of impulsive buying. Meanwhile, face, hedonistic, power resource, and power dominance values did not significantly the tendency of impulsive buying.
\end{abstract}

Keywords: impulsive buying tendency, personal value, Indonesian

\section{Pendahuluan}

Para ekonom klasik memandang proses pembelian barang yang dilakukan manusia dengan pendekatan rasional, atau sejauh mana suatu barang dapat memenuhi kebutuhannya. Tetapi, pada praktiknya saat ini, proses konsumsi seseorang terhadap barang tidak lagi didasarkan pada fungsi atau utilitas barang tersebut. Studi Kahneman dan Tversky (1982; 1984) mungkin menjadi salah satu penelitian pijakan yang mengubah paradigma perilaku konsumsi menjadi lebih memiliki sentuhan psikologi. Penelitian tersebut mengungkapkan bagaimana jika keputusan seseorang sangat dipengaruhi dengan untung rugi yang dia persepsikan, bukan nilai untung rugi yang sebenarnya. Thaler (1980) sempat mengungkapkan bagaimana dua ilmu ini memiliki sudut pandang yang berbeda dalam menjelaskan perilaku membeli seseorang. Jika pendekatan ekonomi memberitahu apa yang seharusnya dibeli oleh individu, tetapi sudut pandang psikologilah yang lebih mampu menjelaskan mengapa sebuah produk akhirnya dibeli.

Trentmann (2004) mengemukakan bahwa sebagai akibat posmodernisme, terjadi pergeseran makna konsumsi di dunia. Konsumsi tidak lagi 
dipandang sebagai cara untuk memenuhi kebutuhan, tetapi juga cara untuk menunjukkan jati diri (Verplanken \& Sato, 2011), menjaga relasi sosial hingga bagaimana menunjukkan status sosial pada masyarakat (Griskevicius, Tybur, \& van den Bergh, 2010).

Pergeseran makna ini membuat para ahli mencoba mencari penjelasan lebih lanjut mengenai fenomena-fenomena konsumsi di masyarakat yang tidak sesuai lagi dengan prinsip ekonomi. Salah satu fenomena tersebut adalah pembelian impulsif yang, jika meminjam istilah Verplanken dan Sato (2011), fenomena yang merusak total kaidah manusia sebagai 'homo economicus'. Berdasarkan penelitian sebelumnya yang menunjukkan bahwa konsumsi dapat menjadi cerminan nilai seseorang (Griskevicius dkk., 2010; Kacen \& Lee, 2002; Verplanken \& Holland, 2002), penelitian kali ini akan melihat sejauh mana peranan nilai seseorang dapat memengaruhi intensinya untuk membeli secara impulsif.

\section{Mengapa Seseorang Membeli secara Impulsive?}

Rook dan Gardner (1993) menyatakan pembelian impulsif adalah pembelian yang sifatnya tidak terencana dan biasanya diikuti oleh emosi dalam prosesnya. Perasaan bahwa 'aku harus memilikinya saat ini' mendominasi seseorang yang membeli barang secara impulsif. Konstruk ini sering kali disejajarkan dengan pembelian kompulsif tetapi sesungguhnya keduanya adalah konstruk yang berbeda. Pembelian kompulsif memiliki sifat adiktif yang terkadang dapat membahayakan diri sendiri (Schiffman, Kanuk \& Wisenbilt, 2015), sementara pembelian impulsif dilakukan hanya karena saat itu dia merasa 'ingin'.

Penelitian-penelitian mengenai anteseden pembelian impulsif banyak berbicara mengenai kondisi internal seseorang, misalnya bagaimana emosi memengaruhi pembelian impulsif ataupun suasana yang menunjang emosi tersebut (Beatty \& Ferrel, 1998; Herabadi, Verplaken, \& Van Knipppenber, 2009). Kondisi internal lain yang disinyalir berperan dengan perilaku membeli impulsif adalah kepribadian. Kepribadian seseorang diketahui memengaruhi pembelian impulsif, baik pada partisipan di Amerika Serikat (Youn \& Faber, 2000), Hong Kong (Thompson \& Prendergarst, 2015) maupun mereka yang tinggal di Indonesia (Verplanken \& Herabadi, 2001). Seseorang dengan nilai consciousness tinggi yang erat dengan kontrol diri serta extraversion tinggi digambarkan cenderung lebih tidak terlibat dalam perilaku impulsif. Trait-trait yang sejalan dengan kepribadian, seperti kontrol diri ataupun sikap terhadap impulsivitas diketahui juga berperan terhadap pembelian impulsif. Hal eksternal diketahui juga memengaruhi perilaku impulsif. Atmosfer toko yang seolah mengundang atau lagu yang meningkatkan adrenalin dapat meningkatkan kecenderungan seseorang untuk membeli barang secara impulsif (Morrin \& Chebat, 2005).
Dari paparan di atas, terlihat meskipun telah banyak penelitian yang mencoba menjelaskan anteseden pembelian impulsif, tetapi riset sebelumnya, terutama di Indonesia, belum memperhatikan bagaimana nilai dapat memengaruhi perilaku ini. Nilai (Boer \& Fischer, 2013; Schwartz, 1992, 2006) memberikan pemaknaan terhadap tujuan akhir dari tingkah laku manusia sehingga memberikan makna yang lebih dalam tentang mengapa seseorang melakukan sesuatu. Nilai adalah tujuan (end-state) yang dapat menjadi gambaran motivasi seseorang melakukan sesuatu. Nilai yang berbeda dapat memiliki peran pada perilaku atau sikap yang sama, tetapi tentu dengan alasan yang berbeda (Bardi \& Schwartz, 2003). Seseorang dengan nilai power tinggi dapat menunjukkan perilaku menolong yang sama dengan mereka yang memiliki nilai benevolence tinggi, tetapi yang awal lebih karena ingin menunjukkan dia 'lebih' mampu, dan yang lain karena murni ingin menolong (Arthaud-day, Rode, \& Turnley, 2012).

Nilai juga menjadi evaluasi normatif seseorang dalam melakukan sesuatu (Schwartz, 2006). Ketika sebuah tingkah laku, baik dari diri maupun orang lain, sejalan dengan nilai yang dianggap penting, maka evaluasi seseorang akan perilaku tersebut akan positif. Akibatnya, perilaku tersebut akan lebih mungkin untuk dilakukan. Sebaliknya, jika tingkah laku tidak sejalan dengan nilai yang dianut, maka evaluasi terhadap perilaku tersebut menjadi negatif. Nilai sebagai bagian dari evaluasi ini berperan apakah seseorang akan mungkin untuk melakukan suatu perilaku tertentu atau tidak. Rook dan Fisher (1995) mengemukakan ada mekanisme evaluasi yang sebenarnya juga memengaruhi apakah seseorang cenderung akan melalukan perilaku pembelian impulsif. Penelitian tersebut direplikasi oleh Negara dan Dharmmesta (2003) di Indonesia dan menyatakan bahwa adanya evaluasi normatif yang turut memoderatori sifat impulsif dengan pembelian impulsif ini. Ketika pembelian impulsif dievaluasi sebagai sesuatu yang positif, maka cenderung akan dilakukan oleh seseorang.

Dalam penelitian kali ini, ada dua buah jenis nilai yang ingin kami uji perannya terhadap tendensi dalam pembelian impulsif, yaitu nilai personal (Schwartz, 1992, 2006; Schwartz \& Cieciuch, 2016) dan nilai berbelanja (Yu \& Bastin, 2010). Nilai personal bersifat lebih umum sementara nilai berbelanja terfokus pada aktivitas berbelanja saja. Ada lima buah nilai personal berdasarkan teori nilai Schwartz (2012) yang akan diuji dalam penelitian ini, yaitu face, power resource, power dominance, hedonism, dan humility.

Kelima nilai tersebut dipilih karena berdasarkan penelitian sebelumnya berkaitan dan memiliki peran terhadap perilaku pembelian impulsif. Power dominance yang tinggi maka seseorang akan menganggap jika mampu mendominasi orang lain adalah hal yang penting (Schwartz \& Cieciuch, 2016). Pembelian suatu barang dapat menjadi sinyal seseorang untuk menunjukkan dominasinya akan 
orang lain (Griskevicius dkk., 2010). Sehingga, seseorang dengan nilai power dominance tinggi akan cenderung untuk membeli barang secara impulsif. Nilai selanjutnya adalah power-resource, atau nilai yang mengacu pada keinginan untuk mengkontrol melalui kepemilikan sumber daya, baik sumber daya diri pribadi ataupun sumber daya sosial (Schwartz \& Cieciuch, 2016). Pembelian impulsif diketahui dapat menjadi simbol untuk mengklarifikasi ataupun mengekspresikan identitas sosial seseorang, terutama ketika pembelian tersebut menjadi gaya hidup (Verplanken \& Sato, 2011). Sehingga, jika dikaitkan dengan nilai power-resource, pembelian impulsif dapat menjadi cara seseorang untuk menunjukkan bahwa dia lebih mampu mengontrol sumber daya dengan membeli 'lebih'.

Sementara, nilai face menunjukkan bagaimana seseorang merasa penting menyelamatkan citra dirinya sehingga aspek kepemilikan barang menjadi penting (Schwartz, 2012). Selain menunjukkan dominasi, pembelian impulsif juga diketahui menjadi salah satu bentuk penjagaan citra diri bagi seseorang (Dittmar, Beatie, \& Friese, 1996). Sehingga, seseorang dengan nilai face tinggi akan cenderung untuk terlibat dalam pembelian impulsif sebagai upayanya untuk menjaga citra dirinya. Nilai hedonisme mungkin yang paling diketahui memiliki kecenderungan kuat berperan terhadap perilaku pembelian impulsif. Hedonisme sendiri berasal dari kebutuhan organisme akan hal-hal yang memuaskan dirinya. Motivasinya adalah pemenuhan hasrat dan kesenangan. Seseorang dengan nilai hedonis akan menganggap hal - hal yang menyenangkan dirinya sebagai hal yang penting (Caprara, Schwartz, Capanna, Vecchione, \& Barbaranelli, 2006). Sehingga, seseorang dengan nilai hedonis tinggi dapat memiliki tendensi pembelian impulsif yang tinggi pula karena hasratnya ingin memuaskan dirinya. Sementara berbeda dengan nilai-nilai sebelumnya, humility berkaitan dengan kesederhanaan dan ketidakinginan untuk menonjol (Schwartz \& Cieciuch, 2016). Meskipun seolah mestinya berkaitan negatif dengan perilaku pembelian impulsif, penelitian yang dilakukan pada sampel-sampel Asia, misalnya di India (Badgaiyan \& Verma, 2010) dan di Pakistan (Jalees, 2009) menunjukkan bahwa nilainilai yang berkaitan dengan konformitas atau keinginan untuk merasa 'sama' atau tidak ingin 'menonjol' justru berperan positif terhadap perilaku ini.

Selain kelima nilai personal, shopping value atau nilai berbelanja seseorang juga menjadi salah satu anteseden pembelian impulsif. Berbeda dengan nilai personal yang cenderung umum, shopping value telah mengarah pada nilai atau pemaknaan seseorang terhadap perilaku berbelanja itu sendiri. Hedonic value shopping adalah pemaknaan mengenai pembelian karena untuk memuaskan perasaan berbelanja itu sendiri (Yu \& Bastin, 2010). Pemaknaan ini bersifat sangat subjektif dan personal, serta sangat dipengaruhi oleh pengalaman sebelumnya. Hedonic Value Shopping (HVS) menggambarkan berbelanja lebih sebagai pengalaman emosional, sementara Utilitarian Value Shopping (UVS) memandang berbelanja sebagai suatu cara pemenuhan kebutuhan semata. Penelitian sebelumnya mengungkapkan jika hedonic shopping value lah yang berperan terhadap perilaku berbelanja impulsif, sementara utilitarian tidak memiliki peran yang signifikan (Yu \& Bastin, 2010).

\section{Metode Penelitian}

\section{Partisipan}

Data dikumpulkan dengan menggunakan survei lapor diri dengan menggunakan bantuan googleform. Peneliti kemudian menyebarkan tautan survei tersebut pada media sosial serta Whatsapp Group. Sebagian besar partisipan adalah perempuan (120 orang / 74\%), sementara sisanya adalah lakilaki. Partisipan berusia pada rentangan 19 hingga 65 tahun $(M=30,01 ; S D=13,21)$.

\section{Pengukuran}

Instrumen survei terdiri dari beberapa item untuk mengukur: (1). Data demografi, (2) Nilai Personal, (3) Nilai Berbelanja serta (4) Intensi untuk Membeli Impulsif. Nilai personal diukur dengan menggunakan alat ukur PVQ (Personal Value Schwartz) yang dikembangkan oleh Schwartz (2006; 2012). Alat ukur ini terdiri dari 57 item yang terbagi menjadi 19 subdimensi, sehingga masing-masing subdimensi terwakili oleh tiga hingga empat item. Dalam setiap item, partisipan diminta untuk memilih seberapa miripkah orang yang dijelaskan dalam item tersebut dengan dirinya (skala likert 1-5, "sangat tidak mirip dengan saya - sangat mirip dengan saya"). Meskipun hanya lima subdimensi yang akan digunakan dalam penelitian ini, tetapi penelitian tetap menggunakan satu set alat ukur yang terdiri dari 19 subdimensi tersebut. Schwartz (2006) mengungkapkan teori nilai personal berbentuk circular, sehingga, nilai yang digunakan dalam persamaan regresi adalah nilai rata-rata terpusat (mean centered) yang didapat dari nilai mentah (raw score) masing-masing item dalam dimensi tertentu dikurangi dengan nilai rata-rata (mean score) keseluruhan nilai (19 sub dimensi) individu tersebut. Untuk masing-masing dimensi, nilai cronbach alpha adalah 0,703 untuk power Dominance, 0,677 untuk power Resources, 0,538 untuk humility, 0, 814 untuk face, serta 0,623 untuk hedonic.

Nilai berbelanja diukur dengan menggunakan alat ukur nilai hedonic dan utilitarian yang dikembangkan oleh Yu dan Bastin (2010). Nilai berbelanja hedonic terdiri dari 13 item (Contoh item: "Dibandingkan dengan hal lain, menghabiskan waktu untuk berbelanja sangat menyenangkan".) sementara nilai berbelanja utilatirian terdiri dari 10 item (contoh item : "Saya tidak membeli barang tanpa adanya diskon yang bagus"). Nilai cronbach alpha untuk nilai berbelanja hedonis adalah 0,909 sementara nilai berbelanja utilitarian adalah 0,346. 
Sementara untuk tendensi dalam pembelian impulsif menggunakan adaptasi alat ukur yang telah dikembangkan oleh Rook dan Fisher (1995) yang terdiri dari 4 buah item. Salah satu contoh butir adalah "Ketika berbelanja, saya membeli barang yang tidak saya rencanakan untuk membelinya". Nilai reliabilitas cronbach alpha untuk pembelian impulsif adalah 0,803. Semua adaptasi dan uji keterbacaan telah dilakukan kepada alat ukur ini sesuai dengan rekomendasi dari Beaton, Bombardier, Guillemin, Ferraz, \& Ferraz (2000) yaitu melalui proses translasi, sintesis, dan translasi kembali kebahasa asal.

\section{Desain dan Prosedur}

Desain penelitian ini korelasional dengan melihat bagaimana peranan dua jenis nilai terhadap tendensi pembelian impulsif. Data dikumpulkan dengan menggunakan survei online dengan bantuan gform. Partisipan diminta kesediaannya untuk mengisi secara sukarela pada awal laman survei. Pada akhir laman, mereka diberikan kesempatan untuk menanyakan hasil penelitian. Mereka kemudian diukur data demografi, nilai personal, nilai shopping serta tendensi dalam pembelian impulsif.

\section{Teknik analisis}

Teknik analisis yang digunakan adalah analisis regresi hirarki untuk mengetahui hubungan langsung nilai seseorang (power-domination, power resource, face, hedonic dan humiliation), nilai berbelanja seseorang (utilitarian dan hedonic) dengan tendensi untuk melakukan pembelian impulsif. Baseline dalam studi ini adalah data demografi yang dalam penelitian sebelumnya diketahui dapat memengaruhi pembelian impulsif (usia, jenis kelamin dan pendapatan). Pada penelitian sebelumnya, diketahui jika perempuan dan seseorang dengan pendapatan lebih tinggi memiliki tendensi yang lebih besar untuk melakukan pembelian impulsif (Badgaiyan \& Verma, 2014). Sementara. usia lebih tinggi memiliki tendensi untuk tidak melakukan pembelian impulsif. Semua analisis akan dilakukan dengan menggunakan SPSS versi 20.

\section{Hasil Penelitian}

Hasil dari skor Mean, Standard Deviasi (SD), dan korelasi pearson keseluruhan konstruk dapat dilihat pada tabel 1. Seperti yang terlibat pada table, terlihat jika dari lima buah nilai personal, hanya nilai humility yang memiliki korelasi signifikan dengan tendensi pembelian impulsif $(r=0,139, p<0,05)$ sementara keempat nilai personal lainnya tidak memiliki korelasi yang signifikan. Nilai face memiliki korelasi signifikan pada nilai utilitarian $(r=0,129, p<$ $0,05)$ dan nilai hedonis $(r=0,188, \mathrm{p}<0,05)$.

Selanjutnya, dilakukan regresi hirarki untuk menguji peranan nilai personal serta nilai berbelanja terhadap IBT (Impulsive Buying Tendency). Adapun hasil regresi hierarki dapat dilihat pada tabel 2 .

Dari hasil pada tabel 2, terlihat bahwa variabel demografi, yaitu jenis kelamin, usia dan pendapatan dapat menjelaskan $4 \%$ varian pada IBT $\left(R^{2}=0,04, \mathrm{~F}(1\right.$, $163)=3,271 p<0,01)$. Jenis kelamin memiliki peranan signifikan paling tinggi dengan nilai $\beta=-0,232$ $(p<0,01)$, di mana perempuan memiliki tendensi lebih besar untuk berbelanja secara impulsif. Penambahan

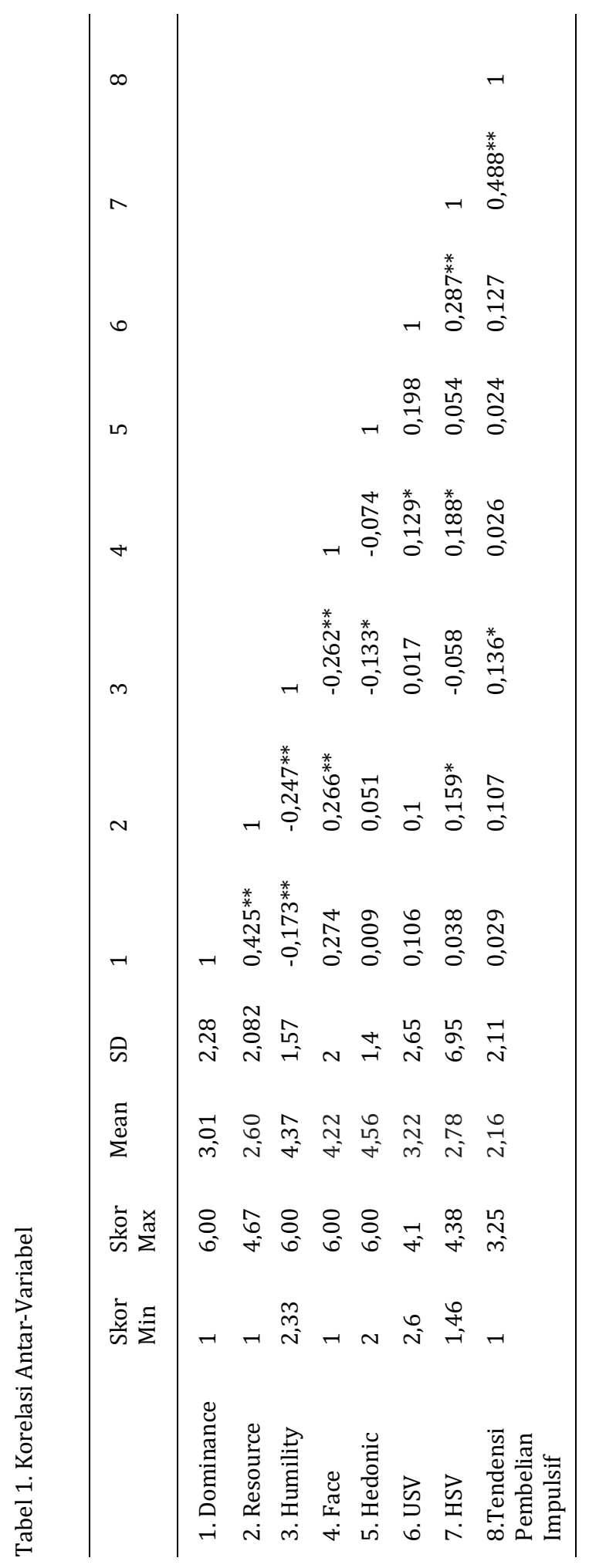


Tabel 2. Regresi Hirarki

Tendensi Pembelian Impulsif

\begin{tabular}{|c|c|c|c|}
\hline & Regresi 1 & Regresi 2 & Regresi 3 \\
\hline $\begin{array}{l}\text { Step } 1 \text { : Variabel Kontrol } \\
\text { Jenis Kelamin }\end{array}$ & $-0,232^{* *}$ & $-0,238^{* *}$ & $-0,092$ \\
\hline Usia & $-0,065$ & $-0,039$ & 0,031 \\
\hline Pendapatan & $-0,009$ & $-0,025$ & $-0,008$ \\
\hline \multicolumn{4}{|l|}{ Step 2 : Nilai Personal } \\
\hline Face & & 0,033 & $-0,044$ \\
\hline Humility & & $0,194^{*}$ & $0,183^{*}$ \\
\hline Hedonistic & & 0,042 & 0,014 \\
\hline Power Resource & & 0,134 & 0,082 \\
\hline Power Dominance & & 0,008 & 0,026 \\
\hline \multicolumn{4}{|l|}{ Step 3 : Nilai Berbelanja } \\
\hline Utilitarian Value Shopping & & & $-0,011$ \\
\hline Hedonistic Value Shopping & & & $0,472^{* *}$ \\
\hline Nilai $F$ & $3,271^{* *}$ & 2,166 & $5,995^{* *}$ \\
\hline $\operatorname{Adj} R^{2}$ & 0,040 & 0,054 & 0,235 \\
\hline$R$ & 0,058 & 0,101 & 0,282 \\
\hline$\Delta R$ & & 0,043 & $0,181^{* *}$ \\
\hline
\end{tabular}

$* p<0,05 ;{ }^{* *} p<0,01$

nilai-nilai personal pada tahapan kedua tidak memperikan peningkatkan nilai $R$ square yang signifikan $(\Delta R=0,043, p>0,05)$. Meskipun demikian, nilai humility berperan terhadap tendensi berbelanja impulsif $(\beta=0,194, p<0,05)$. Pada regresi ketiga, terjadi kenaikan $R^{2}$ yang signifikan $(\Delta R=0,181, p>$ $0,01)$ dengan variabel HVS menyumbang peranan paling signifikan $(\beta=0,472, p<0.01)$, sementara UVS tidak signifikan berperan terhadap IBT $(\beta=-0,011, p>$ $0,05)$. Secara bersama-sama, variabel-variabel menjelaskan varian IBT sebesar 23,5\% $\left(R^{2}=0,235\right.$, $F(1,163)=5,995, p<0,05)$. Variabel yang dapat menjelaskan IBT secara signifikan adalah jenis kelamin, usia, pendapatan serta nilai personal dan nilai berbelanja.

\section{Diskusi}

Hasil ini mendukung sebagian hipotesis, yaitu nilai berbelanja hedonis seseorang, bukannya nilai utilitarian, memprediksi tendensi pembelian impulsif. Sementara itu, nilai personal diketahui tidak dapat memprediksi pembelian impulsif seseorang. Selain itu, juga ditemukan bahwa jenis kelamin juga dapat memprediksi tendensi pembelian impulsif, tetapi tidak dengan usia dan pendapatan.

Meskipun nilai personal secara keseluruhan tidak memiliki peranan signifikan, tetapi salah satu dimensi nilai personal berperan signifikan terhadap IBT, yaitu adalah nilai humility. Justru, nilai-nilai yang dianggap 'dekat' dengan IBT (power resource, face ataupun hedonic) tidak menunjukkan peranan yang signifikan. Sementara, untuk nilai berbelanja diketahui hanya hedonic shopping value yang signifikan berpengaruh, sementara utilitarian tidak secara signifikan memengaruhi tendensi pembelian impulsif. Humility menurut Schwartz (2012) adalah nilai yang menunjukkan ketidakinginan untuk menonjol atau berbeda dari orang lain. Nilai ini juga erat kaitannya dengan nilai conformity. Meskipun penekanan konstruknya berbeda, hasil ini sejalan dengan beberapa temuan mengenai peranan conformity dan pembelian impulsif pada beberapa negara di Asia, misalnya di Pakistan (Jalees, 2009) dan India (Badgaiyan \& Verma, 2014).

Salah satu hal yang mungkin bisa menjelaskan hasil ini adalah pembelian impulsif sering kali dilakukan tidak hanya karena ingin menyenangkan diri semata, tetapi juga sebagai bentuk bagaimana kita ingin dilihat oleh orang lain. Dittmar dkk. (1996) mengemukakan jika pembelian dan pemilikan barang menjadi simbol identitas, atau bagaimana kita ingin dilihat oleh orang lain. Lebih jauh lagi, Yurchisin dan Johnson (2004) mengemukakan hal yang serupa, yaitu bagaimana seseorang membeli dengan tiba-tiba karena ingin menunjukkan definisi diri tertentu. Sehingga, jika dikaitkan pada hasil penelitian ini, 
pembelian impulsif dianggap sebagai salah satu cara untuk menunjukkan nilai humility seseorang, atau bagaimana seseorang menunjukkan jika dirinya tidak berbeda dengan orang lain.

Dameyasani dan Abraham (2013) menuturkan jika saat ini seseorang cenderung berbelanja dengan berkelompok. Jika dikaitkan dengan masyarakat Indonesia yang cenderung embeddedness atau terikat dengan kelompoknya (Schwartz, 2006), memperbesar potensi untuk 'tiba-tiba' berbelanja karena ingin sama dengan kelompok. Selain itu, mengingat penelitian ini dilakukan pada orang-orang perkotaan, di mana pembelian impulsif sudah dianggap sebagai suatu hal yang biasa (Trentmann, 2004), maka menjadi wajar jika seseorang dengan nilai humility justru merasa pembelian impulsif adalah suatu cara agar dia 'tidak berbeda' dengan orang lain di sekitarnya. Lee dan Kacen (2008) juga menekankan bagaimana seseorang yang berasal dari budaya kolektivis lebih "puas" ketika melakukan pembelian impulsif saat terlihat oleh orang-orang sekitarnya, berbeda dengan studi yang dilakukan oleh Dittmar (2004) yang mengemukakan bahwa sering kali timbul penyesalan pasca-pembelian impulsif pada orang di Barat.

Nilai hedonic yang selama ini identik dengan kesenangan diketahui tidak berkaitan dengan pembelian impulsif, tetapi nilai hedonik pada berbelanja (hedonic shopping value) sangat berperan terhadap pembelian impulsif. Tidak berkaitannya nilai yang merepresentasikan hedonistic terhadap pembelian impulsive sejalan dengan penelitian yang dilakukan oleh Chavosh, Halimi dan Namdar (2011). Hal ini bisa jadi dikarenakan jika nilai hedonic bersifat universal pada tiap aspek dalam hidup atau berkaitan dengan tujuan hidupnya secara luas (Schwartz, 1996), sedangkan nilai berbelanja lebih pada pemaknaan seseorang terhadap perilaku spesifik yaitu berbelanja.

Secara garis besar, hasil ini setidaknya menunjukkan keterkaitan antara nilai dan sikap ataupun perilaku bisa jadi sangat dipengaruhi pada di mana individu tersebut berada. Pada masyarakat kolektivis seperti Indonesia, India ataupun Pakistan, diketahui faset-faset yang berkaitan dengan konformitas, ternyata dapat memiliki pengaruh terhadap pembelian impulsif. Bardi dan Schwartz (2003) menuturkan pemunculan nilai dalam sebuah tingkah laku sangat dipengaruhi oleh orang-orang di sekitar mereka. Kacen dan Lee (2002) mengungkapkan masyarakat Asia yang kolektivis lebih tidak terlibat dalam pembelian impulsif bila dibandingkan dengan konsumen individualis di Eropa. Meskipun kedua masyarakat tersebut memiliki trait impulsif yang tidak jauh berbeda, tetapi pada masyarakat Asia, kaitan trait-perilaku pembelian impulsif lebih lemah, menunjukkan adanya norma sosial yang mungkin membuat perilaku ini lebih tidak diterima (Rook \& Fisher, 1995). Hal inilah yang menjadikan manifestasi suatu nilai personal hedonic kurang terlihat pada perilaku pembelian impulsif di masyarakat Indonesia.
Meskipun penelitian ini memberikan pandangan baru mengenai keterkaitan nilai personal dan tendensi dalam pembelian impulsif, tidak dapat dipungkiri jika ada beberapa limitasi yang dapat dijadikan masukan untuk penelitian sesudahnya. Berdasarkan penelitian Vohs dan Faber (2007) mengungkapkan adanya urgensi untuk mulai membedakan "wanting" dan "liking" dalam setiap penelitian mengenai impulsivitas, di mana "wanting" atau "keinginan" lebih pada adiksi yang tidak menyuguhkan kenikmatan, berbeda dengan "liking" yang secara sistem neurologis (Berridge, 2003) berkaitan dengan kesenangan. Penelitian ini belum secara eksplisit membedakan antara adiksi sebagai keinginan ataupun sebagai kesenangan, sehingga dapat menjadi masukan untuk penelitian selanjutnya.

Tendensi pembelian impulsif dalam penelitian ini masih general, padahal penelitian sebelumnya mengungkapkan bagaimana perbedaan barang dapat menunjukkan tendensi impulsif yang berbeda. Produk yang lebih tidak sehat misalnya lebih dikaitkan dengan impulsifitas daripada produkproduk yang sehat (Shiv \& Fedorikhin, 1999), sehingga bisa jadi tendensi impulsivitas pada kedua produk akan berbeda. Isu lain adalah adanya common method varians yang dapat melebihkan peranan sebenarnya (Podsakoff, MacKenzie, Lee \& Podsakoff, 2003). Sehingga untuk penelitian selanjutnya, penggunaan metode pengambilan data yang lebih bervariasi sangat dianjurkan.

\section{Kesimpulan}

Penelitian ini bertujuan untuk melihat peran nilai personal dan nilai berbelanja dengan pembelian impulsif. Dengan menggunakan studi korelasional, ditemukan bahwa pemaknaan terhadap perilaku berbelanjalah yang lebih menjadi alasan seseorang dalam melakukan pembelian impulsif bila dibandingkan dengan nilai personal. Oleh karena itu, penelitian ini mengindikasikan bahwa meskipun seseorang memiliki nilai hedonis atau kecenderungan untuk melihat kesenangan sebagai hal yang penting, ketika tidak diikuti dengan pemaknaan hedonis terhadap perilaku belanja maka tidak dapat menjadi anteseden intensi untuk berbelanja impulsif

\section{Daftar Pustaka}

Arthaud-Day, M. L., Rode, J. C., \& Turnley, W. H. (2012). Direct and contextual effects of individual values on organizational citizenship behavior in teams. Journal of Applied Psychology, 97(4), 792-807. doi: 10.1037/a0027352

Dameyasani, A. W., \& Abraham, J., (2013). Impulsive buying, cultural values dimensions, and symbolic meaning of money: A study on college students in Indonesia's capital city and its surrounding. International Journal of Research 
Studies in Psychology, 2(3), 35-52. doi:10.5861/ijrsp.2013.374

Badgaiyan, A. J., \& Verma, A. (2014). Intrinsic factors affecting impulsive buying behaviourEvidence from India. Journal of Retailing and consumer services, 21(4), 537-549. doi: 10.1016/j.jretconser.2014.04.003

Bardi, A., \& Schwartz, S. H. (2003). Values and behavior: Strength and structure of relations. Personality and social psychology bulletin, 29(10), 1207-1220. doi: 10.1177/0146167203254602

Beatty, S. E., \& Ferrell, M. E. (1998). Impulse buying: Modeling its precursors. Journal of retailing, $74(2)$, 169-191. doi: 10.1016/s00224359(98)90009-4

Beaton, D. E., Bombardier, C., Guillemin, F., \& Ferraz, M. B. (2000). Guidelines for the process of cross-cultural adaptation of self-report measures. Spine, 25(24), 3186-3191. doi: 10.1097/00007632-200012150-00014

Berridge, K. C. (2003). Pleasures of the brain. Brain and cognition, 52(1), 106-128. doi: 10.1016/s0278-2626(03)00014-9

Boer, D., \& Fischer, R. (2013). How and when do personal values guide our attitudes and sociality? Explaining cross-cultural variability in attitude-value linkages. Psychological Bulletin, 139(5), 1113-1147. doi:10.1037/a0031347

Caprara, G. V., Schwartz, S., Capanna, C., Vecchione, M., \& Barbaranelli, C. (2006). Personality and politics: Values, traits, and political choice. Political Psychology, 27(1), 1-28. doi:10.1111/j.14679221.2006.00447.x

Chavosh, A., Halimi, A.B., \& Namdar, J., (2011, February). The contribution of product and consumer characteristics to consumer's impulse purchasing behaviour in Singapore. Paper presented at Proceedings of International Conference on Social Science and Humanity. Retrieved from http://ipedr.com/vol5/no1/53H00124.pdf

Dittmar, H., Beattie, J., \& Friese, S. (1996). Objects, decision considerations and self-image in men's and women's impulse purchases. Acta psychologica, 93(1), 187-206. doi: 10.1016/0001-6918(96)00019-4

Dittmar, H. (2004). Understanding and diagnosing compulsive buying. Handbook of addictive disorders: A practical guide to diagnosis and treatment, 42(04), 411-450. doi: 10.5860/choice.42-2250

Griskevicius, V., Tybur, J. M., \& Van den Bergh, B. (2010). Going green to be seen: status, reputation, and conspicuous conservation. Journal of personality and social psychology, 98(3), 392-404. doi: 10.1037/e621072012217

Herabadi, A. G., Verplanken, B., \& Van Knippenberg, A. (2009). Consumption experience of impulse buying in Indonesia: Emotional arousal and hedonistic considerations. Asian Journal of
Social Psychology, 12(1), 20-31. doi: 10.1111/j.1467-839x.2008.01266.x

Jalees, T. (2009). An empirical analysis of impulsive buying behavior in Pakistan. Market Forces, 5(6), 149-156. Retrieved from http://www.pafkiet.edu.pk/marketforces/ind ex.php/marketforces/article/view/219/220

Kacen, J. J., \& Lee, J. A. (2002). The influence of culture on consumer impulsive buying behavior. Journal of Consumer Psychology, 12(2), 163-176. doi:10.1207/153276602760078686

Kahneman, D., \& Tversky, A. (1982). The psychology of preferences. Scientific American, 246(1), 160-173. doi: 10.1038/scientificamerican0182160

Kahneman, D., \& Tversky, A. (1984). Choices, values, and frames. American Psychologist, 39(4): 341-350. doi: 10.1037//0003-066x.39.4.341

Lee, J. A., \& Kacen, J. J. (2008). Cultural influences on consumer satisfaction with impulse and planned purchase decisions. Journal of Business Research, 61(3), 265-272. doi: 10.1016/j.jbusres.2007.06.006

Morrin, M., \& Chebat, J. C. (2005). Person-place congruency: The interactive effects of shopper style and atmospherics on consumer expenditures. Journal of Service Research, 8(2), 181-191. doi: 10.1177/1094670505279420

Negara, D. J., \& Dharmmesta, B. S. (2003). Normative moderators of impulse buying behavior. Gadjah Mada International Journal of Business, 5(1), 1-14. doi: 0.22146/gamaijb.5394

Schiffman, L. G., \& Kanuk, L. L. Wisenblit J. (2015) Consumer behavior. New York: McGraw-Hill Book Co.

Schwartz, S. H. (1992). Universals in the content and structure of values: Theoretical advances and empirical tests in 20 countries. In Advances in experimental social psychology (Vol. 25, pp. 165). doi: 10.1016/s0065-2601(08)60281-6

Schwartz, S. H. (1994). Are there universal aspects in the structure and contents of human values? Journal of social issues, 50(4), 19-45. doi: 10.1111/j.1540-4560.1994.tb01196.x

Schwartz, S. H. (2006). A theory of cultural value orientations: Explication and applications. Comparative sociology, 5(2), 137-182. doi: 10.1163/ej.9789004158207.i-193.19

Schwartz, S. H. (2012). An overview of the Schwartz theory of basic values. Online readings in Psychology and Culture, 2(1), 11. doi: 10.9707/2307-0919.1116

Schwartz, S.H., \& Cieciuch, J. (2016). Values. International Test Commision: Handbook of Testing and Assesment. doi: 10.1093/med:psych/9780199356942.001.0001

Shiv, B., \& Fedorikhin, A. (1999). Heart and mind in conflict: The interplay of affect and cognition in consumer decision making. Journal of consumer Research, 26(3), 278-292. doi: $10.1086 / 209563$ 
Podsakoff, P. M., MacKenzie, S. B., Lee, J. Y., \& Podsakoff, N. P. (2003). Common method biases in behavioral research: A critical review of the literature and recommended remedies. Journal of applied psychology, 88(5), 879. doi: 10.1037/0021-9010.88.5.879

Rook, D. W., \& Gardner, M. P. (1993). In the mood: Impulse buying's affective antecedents. Research in consumer behavior, 6(7), 1-28. Retrieved from https://www.researchgate.net/publication/2 84059785_In_the_mood_Impulse_buying's_aff ective_antecedents

Rook, D. W., \& Fisher, R. J. (1995). Normative influences on impulsive buying behavior. Journal of consumer research, 22(3), 305-313. doi: $10.1086 / 209452$

Thaler, R. (1980). Toward a positive theory of consumer choice. Journal of Economic Behavior \& Organization, 1(1), 39-60. doi: 10.1016/0167-2681(80)90051-7

Thompson, E. R., \& Prendergast, G. P. (2015). The influence of trait affect and the five-factor personality model on impulse buying. Personality and Individual Differences, 76, 216221. doi: $10.1016 /$ j.paid.2014.12.025

Trentmann, F. (2004). Beyond consumerism: new historical perspectives on consumption. Journal of Contemporary History, 39(3), 373401. doi: $10.1177 / 0022009404044446$

Verplanken, B., \& Herabadi, A. (2001). Individual differences in impulse buying tendency: feeling and no thinking. European Journal of Personality, 15(S1), S71-S83. doi: 10.1002/per.423

Verplanken, B., \& Holland, R. W. (2002). Motivated decision making: Effects of activation and self- centrality of values on choices and behavior. Journal of personality and social psychology, 82(3), 434-447. doi: 10.1037//00223514.82.3.434 .

Verplanken, B., \& Sato, A. (2011). The psychology of impulse buying: An integrative self-regulation approach. Journal of Consumer Policy, 34(2), 197-210. doi: 10.1007/s10603-011-9158-5

Vohs, K. D., \& Faber, R. J. (2007). Spent resources: Selfregulatory resource availability affects impulse buying. Journal of consumer research, 33(4), 537-547. doi: 10.1086/510228

Yurchisin, J., \& Johnson, K. K. (2004). Compulsive buying behavior and its relationship to perceived social status associated with buying, materialism, self-esteem, and apparel-product involvement. Family and Consumer Sciences Research Journal, 32(3), 291-314. doi: $10.1177 / 1077727 \times 03261178$

Youn, S., \& Faber, R. J. (2000). Impulse buying: its relation to personality traits and cues. Advances in Consumer Research, 27(1), 179$185 . \quad$ Retrieved from http://web.a.ebscohost.com/ehost/detail/det ail?vid=0\&sid=b25b4cd8-8176-49d5-848e377481e19c57\%40sessionmgr4007\&bdata=J nNpdGU9ZWhvc3QtbGl2ZQ\%3d\%3d\#AN=66 87575\&db=bth

Yu, C., \& Bastin, M. (2010). Hedonic shopping value and impulse buying behavior in transitional economies: A symbiosis in the Mainland China marketplace. Journal of Brand Management, 18(2), 105-114. doi: 10.1057/bm.2010.32 